\title{
Physiological potential of stylosanthes cv. Campo Grande seeds coated with different materials ${ }^{1}$
}

\author{
Priscilla Brites Xavier²*, Henrique Duarte Vieira², Cynthia Pires Guimarães ${ }^{2}$
}

\begin{abstract}
The aim of this study was to assess the effect of different coatings on the physiological potential of stylosanthes cv. Campo Grande seeds. The treatments were: uncoated seeds; limestone + PVA glue; limestone + sand + PVA glue; limestone + activated carbon + PVA glue; calcium silicate + PVA glue; calcium silicate + sand + PVA glue; calcium silicate + activated carbon + PVA glue. Posteriorly, the seeds were analyzed for water content (WC), maximum diameter (MAD) and minimum diameter (MID), thousand seed weight (TSW), germination test, germination speed index (GSI), mean germination time (MGT), emergence, emergence speed index (ESI), mean emergence time (MET), shoot and root length, fresh and dry matter of shoot and root. The coating increased the TSW, MAD and MID and decreased its WC. The treatments comprising limestone + PVA glue and limestone + sand + PVA glue increased the germination time, but none of the treatments negatively affected the physiological seed quality. Treatment with calcium silicate + PVA glue was outstanding for germination speed index and fresh and dry matter of shoot and root in the stylosanthes cv. Campo Grande seeds coating.
\end{abstract}

Index terms: seed coating, seed coating machine, germination, vigor, Stylosanthes capitata/macrocephala.

\section{Potencial fisiológico de sementes de estilosantes cv. Campo Grande recobertas com diferentes materiais}

\begin{abstract}
RESUMO - Objetivou-se com este trabalho avaliar o efeito de diferentes recobrimentos sobre o potencial fisiológico de sementes de estilosantes cv. Campo Grande. Os tratamentos foram: sementes não recobertas; calcário + cola PVA; calcário + areia + cola PVA; calcário + carvão vegetal + cola PVA; silicato de cálcio + cola PVA; silicato de cálcio + areia + cola PVA; silicato de cálcio + carvão vegetal + cola PVA. Posteriormente, as sementes foram avaliadas quanto ao teor de água (TA), diâmetro máximo (DMA) e mínimo (DMI), peso de mil sementes (PMS), teste de germinação, índice de velocidade de germinação, tempo médio de germinação, emergência, índice de velocidade de emergência, tempo médio de emergência, comprimento da parte aérea e raiz, massa fresca e seca da parte aérea e raiz. Os tratamentos constituídos por calcário + cola PVA e calcário + areia + cola PVA aumentaram o tempo de germinação. Nenhum dos tratamentos prejudicou a qualidade fisiológica das sementes. O tratamento com silicato + cola PVA se destacou para as variáveis, índice de velocidade de germinação, massa fresca e seca da parte aérea e de raiz no recobrimento de sementes de estilosantes cv. Campo Grande.
\end{abstract}

Termos para indexação: recobrimento de sementes, drageadora, germinação, vigor, Stylosanthes.

\section{Introduction}

The Brazilian cattle industry is characterized by having most of its flock raised on pasture; this practice is an economical way to produce and provide food for animals (Ferraz and Felício, 2010). Therefore, the role of fodder plants in this production system is extremely important, both as an income as to its sustainability.

Tropical poaceae generally have lower nutritional quality compared to the temperate ones. Thus, the introduction of tropical Fabaceae (or Leguminosae, commonly known as the legume, pea, or bean family), adapted to the pasture raising system, contributes to the solution of problems of low level of nitrogen in soils and the reduced protein quality available to the animals (Shelton et al., 2005).

Stylosanthes cv. (cultivated variety or cultivar) Campo Grande is a fodder Fabaceae, launched by EMBRAPA (Empresa Brasileira de Pesquisa Agropecuária; Brazilian Corporation of Agricultural Research) in 2007, comprising the physical mixture of improved seeds of Stylosanthes

${ }^{1}$ Submitted on 02/11/2015. Accepted for publication on 04/24/2015.

${ }^{2}$ Universidade Estadual do Norte Fluminense Darcy Ribeiro, Setor de Tecnologia de Sementes, 28013-602 - Campos dos Goytacazes, RJ, Brasil.

*Corresponding author<pri_brites@yahoo.com.br> 
capitata and Stylosanthes macrocephala, at the ratio of $80 \%$ e 20\%, respectively (EMBRAPA Gado de Corte, 2007), and it is promising in providing good quality fodder. This legume is further characterized by having very small seeds (350-400 seeds/g) (EMBRAPA Gado de Corte, 2007), with color ranging from red to brown and black, features that hinder both its tillage as its sowing. In this context, the use of technologies such as coating the seeds, contributes to the solution of problems related to the size and shape of seeds, as it standardizes the seed size and shape, facilitating its distribution, whether manual or mechanical, providing greater precision in sowing (Baudet and Peres, 2004; Nascimento et al., 2009).

The seed coating procedure consists of depositing a dried, inert, fine-grained matter, called filler, and a binder materials, also called adhesive, to the surface of the seeds (Silva and Nakagawa, 1998a). Materials used as cementing must have affinity with the other ingredients; be readily soluble in water; act at low concentrations; become dry and not sticky when dehydrated; form a low viscous solution when rehydrated; and be non-hygroscopic, corrosive nor toxic (Nascimento et al., 2009). Moreover, the filler material should be preferably formed by spherical, uniform beads, with sizes between 0.100 and $0.200 \mathrm{~mm}$, non-hygroscopic, without surface tension, non-hydrophilic, non-corrosive, non-toxic, sterile, must not be an environment for the reproduction of microorganisms, must be insoluble in water or weak acids, with a density of about 1 and must be easy to purchase, with compatible costs (Lopes and Nascimento, 2012).

Among the most studied fillers there is microcellulose (Microcrystalline cellulose (MCC)), sand, dolomite, kaolin, activated carbon, vermiculite, maize flour, wheat flour, tapioca starch, maize starch, Celite ${ }^{\circledR}$ and diatomaceous earth (Silva et al., 2002; Oliveira et al., 2003a; Mendonça et al., 2007; Nascimento et al., 2009; Pereira et al., 2011). The materials used as adhesives are generally organic polymers, starches, natural resins, sugars, animal glue and vegetable mucilages, which are dispersed in water to produce a fluid that can be sprayed (Baudet and Peres, 2004). While improving the morphological characteristics of the seeds, the main obstacle to the use of coated seed is the delayed germination and emergence. Several studies indicate the occurrence of this delay in relation to uncoated seeds, as noted in coated seeds of lettuce (Silva et al., 2002), bell pepper (Oliveira et al., 2003a), supersweet maize (Mendonça et al., 2007), maize (Conceição and Vieira, 2008) and carrot (Nascimento et al., 2009). This delay is due to the arrangement of fine particles and the filling of the pores of the pellet by the cementing agent and water supplied during the procedure, which forms a barrier to the gaseous exchange between the seed and the environment external to the pellet (Silva and Nakagawa, 1998a). However, despite this delay, the final germination rates are similar to those of the uncoated seeds (Silva et al., 2002; Lopes and Nascimento, 2012; Pereira et al., 2011).

With regard to seeds of fodder legumes such as stylosanthes, there is still a scarcity of studies on the coating of these seeds. Considering the size of stylosanthes seeds, this fodder seems promising in the study of seed coating. Thus, the aim of this study was to assess the effect of different types of coating materials on the physiological potential of stylosanthes cv. Campo Grande seeds.

\section{Material and Methods}

Commercial seeds of Stylosanthes capitata/macrocephala cv. Campo Grande I and II were used, previously submitted to mechanical chisel plow with sandpaper number 100 .

As fillers were used: dolomitic limestone $(0.25 \mathrm{~mm})$, calcium silicate $(<0.20 \mathrm{~mm})$, sand $(0.25 \mathrm{~mm})$ and activated carbon powder. And as a cementing material was used a solution of water and extra Cascorez glue based on Polyvinyl acetate (PVA).

The seed coating treatments were as follows: US uncoated seeds; L + PVA (dolomitic limestone + PVA glue); $\mathrm{L}+\mathrm{S}+\mathrm{PVA}$ (dolomitic limestone + sand + PVA glue); $\mathrm{L}+\mathrm{AC}$ + PVA (dolomitic limestone + activated carbon + PVA glue); CS + PVA (calcium silicate + PVA glue) $; \mathrm{CS}+\mathrm{S}+$ PVA glue (calcium silicate + sand + PVA); CS + AC + PVA (calcium silicate + activated carbon + PVA glue) .

The ratios of filler and seeds used were: limestone 3:1 $(\mathrm{w} / \mathrm{w})$, calcium silicate $3: 1(\mathrm{w} / \mathrm{w})$, sand 1:1 (w/w) and activated carbon 0.08:1 (w/w). The PVA-based glue was diluted with water, preheated to $70{ }^{\circ} \mathrm{C}$ (Mendonça et al., 2007), at the ratio of $1: 1(\mathrm{v} / \mathrm{v})$ for use as a binder solution. For the application of the filler materials to be done into layers, the quantities of limestone, calcium silicate and sand were divided into portions of $12.5 \mathrm{~g}$ each, while the activated carbon was divided into portions of $2 \mathrm{~g}$ each.

For the coating procedure, a bench seed coating machine was used, model N10 Newpack, equipped with a stainless steel vat, nozzle for application of the cement solution powered by compressed air at a pressure of 4 bars, a hot air blower and a timer to regulate the length of time of the spray and the blower. The settings used in the procedure were as follows: vat speed of $90 \mathrm{rpm}$, cementing solution spray duration time of 1 second, air blower temperature of $40{ }^{\circ} \mathrm{C}$ and duration time of the connected blower of 1 minute.

One hundred grams of seeds, limestone or calcium silicate, depending on the type of coating used, were placed 
inside the seed coating machine vat together with a portion of filler. Then, the binding solution spray was powered three consecutive times and a portion of the filler material was added again on the seed mass, followed by another application of cement solution. Subsequently, the air blower was activated for 1 minute. This procedure corresponded to a coating layer, and was carried out until the amount of filler ended. For the treatments to which were added more than one filler material, in the case of sand and activated carbon, they were added in the same way, but in the intermediary layers. The layers of activated carbon were added after the third layer with limestone or calcium silicate. The sand layers were added after the seventh layer with these materials. This order was established according to the granulometry of the sand and charcoal, where finer grain size materials should be used in layers closer to the core of the pellet, whereas thicker granulated materials such as sand must be applied in outer layers (Silva and Nakagawa, 1998a).

After coating, the seeds were assessed for physical and physiological characteristics in a laboratory and in a greenhouse. In the laboratory, the physical characteristics were assessed for water content (WC), maximum diameter (MAD), minimum diameter (MID) thousand uncoated and coated seed weight (TSW), while the physiological ones were assessed by means of germination test on paper, first count of germination (FCG), germination speed index (GSI) and mean germination time (MGT). In a greenhouse, the physiological characteristics were assessed by means of the emergence test, emergence speed index (ESI), mean emergence time (MET), shoot length (SL), root length (RL), fresh and dry mass of the shoot (FMS and DMS) and fresh and dry mass of the root (FMR and DMR). The procedures for assessment of the above characteristics were:

Water Content $(W C)$ - determined with two repetitions, by the oven method at $105^{\circ} \mathrm{C}$ for 24 hours (Brasil, 2009) and the results expressed in percentage (wet basis).

Maximum diameter (MAD) and Minimum diameter (MID) - determined with four replications of 50 seeds each for each treatment of coating, which were analyzed by SAS equipment (Seed Analysis System), for the supply of the larger and smaller diameter (MAD and MID, respectively), and the results expressed in millimeters $(\mathrm{mm})$.

Thousand uncoated and coated seed weight (TSW) eight repetitions of 100 seeds each were used, for each coating treatment, according to the methodology (Brasil, 2009).

Germination test - conducted under the Rules for Seed Analysis (Brasil, 2009) with four replications of 50 seeds each, for each coating. The seeds were sown in germination boxes containing two sheets of paper for germination, moistened with distilled water in a volume of 2.5 times the weight of the paper and kept for 10 days in a B.O.D. (Biochemical Oxygen Demand)-type germination chamber with a photoperiod of $16 / 8 \mathrm{~h}$ (dark/light) and alternating temperature of $20-35^{\circ} \mathrm{C}$. The assessments were performed at 4 and 10 days after the start of the test (first count (FCG) and final germination (G), respectively), computing the number of normal seedlings, abnormal seedlings (AS) and non-germinated seeds (NGS), according to the criteria established by Brasil (2009), and the results expressed as a percentage. Throughout the test, daily counts were performed to determine the germination speed index (GSI) by the formula proposed by Maguire (1962) and the mean germination time (MGT), according to Edmond and Drapala (1958).

Emergence test - conducted in a greenhouse where the seeds were sown in plastic trays with a capacity of 2.2 liters of substrate, containing a mixture of sand and soil (2:1) (v/v). Daily counts of the number of emerged plants were held for a period of 30 days. At the end, were determined the percentage of emergence (E), the emergence speed index (ESI), according to a formula by Maguire (1962), and the mean emergence time (MET), according to an adaptation by Edmond and Drapala (1958). At the end of 30 days, the plants were carefully removed from the trays and had their roots properly washed for measuring shoot length (SL) and root length (RL). Subsequently, the shoot was separated from the root and both were stored in paper bags and weighed on precision scales to determine the fresh mass of the shoot (FMS) and the fresh mass of the root (FMR). Then the bags were kept in an air forced circulation stove at $65^{\circ} \mathrm{C}$ for 72 hours to determine the dry mass of the shoots (DMS) and the dry mass of the roots (DMR) (Silva and Queiroz, 2006).

Statistical analysis was performed using a completely randomized design model for the variables: water content, maximum and minimum diameters, first count of germination, germination percentage, abnormal seedlings and nongerminated seeds, germination speed index, mean germination time. For the variables percentage of emergence, emergence speed index, mean germination time, shoot and root length and fresh and dry mass of shoot and root, a randomized block design model was employed, with four replications of 50 seeds each. For determining the weight of a thousand seeds, a descriptive analysis of the data was performed. The data for the MET were transformed to $\sqrt{ } \mathrm{x}$ due to not following a normal distribution.

The data were submitted to the analysis of variance and the means were compared by the Duncan test at 5\% probability with the help of the free software Assistência Estatística (ASSISTAT) 7.6 beta (Silva, 2013). 


\section{Results and Discussion}

The coating of seeds with the proposed materials promoted increases in TSW of 1.6 to 2.3 times in the coated seeds compared to the uncoated ones (Table 1). Medeiros et al. (2004) found increases of 2.5 and 4.0 times in carrot TSW, due to the ratio between the filler material (vermiculite) and seeds. The great advantage in increasing the seed weight and consequently the seed size is in the ease of sowing these seeds, whether manually or mechanically (Medeiros et al., 2004; Nascimento et al., 2009; Gadotti and Puchala, 2010). Therefore, the different coating treatments assessed in this work would facilitate the sowing of stylosanthes seeds, not only by the increase in the TSW, but also for changing and standardizing their color and shape.

Table 1. Thousand seed weight (TSW) (g), maximum diameter (MAD) (mm), minimum diameter (MID) (mm) and water content (WC) (\%) of stylosanthes cv. Campo Grande seeds coated with the following treatments: US - uncoated seeds; L + PVA (dolomitic limestone + PVA); L + S + PVA (dolomitic limestone + sand + PVA); L + AC + PVA (dolomitic limestone + activated carbon + PVA); CS + PVA (calcium silicate + PVA); CS + S + PVA (calcium silicate + sand + PVA); CS + AC + PVA (calcium silicate + activated carbon + PVA).

\begin{tabular}{lcccc}
\hline \multicolumn{1}{c}{ Treatment } & TSW $(\mathrm{g})$ & MAD $(\mathrm{mm})$ & MID $(\mathrm{mm})$ & WC $(\%)$ \\
\hline US & 2.42 & $2.48 \mathrm{e}$ & $1.53 \mathrm{e}$ & $10.5 \mathrm{a}$ \\
L + PVA & 4.15 & $2.67 \mathrm{~cd}$ & $1.80 \mathrm{c}$ & $6.4 \mathrm{bc}$ \\
L + S + PVA & 5.59 & $2.75 \mathrm{~b}$ & $1.95 \mathrm{a}$ & $1.9 \mathrm{e}$ \\
L + AC + PVA & 4.64 & $2.64 \mathrm{~d}$ & $\mathrm{c}$ & $6.3 \mathrm{~cd}$ \\
CS + PVA & 3.78 & $2.75 \mathrm{~b}$ & $1.80 \mathrm{c}$ & $6.7 \mathrm{~b}$ \\
CS + S + PVA & 4.53 & $2.87 \mathrm{a}$ & $1.86 \mathrm{~b}$ & $5.9 \mathrm{~d}$ \\
CS + AC + PVA & 3.76 & $2.72 \mathrm{bc}$ & $1.74 \mathrm{~d}$ & $6.6 \mathrm{bc}$ \\
\hline Average & - & 2.70 & 1.78 & 6.76 \\
CV $(\%)$ & - & 1.31 & 1.60 & 2.57 \\
\hline
\end{tabular}

The coating treatments in which there was the addition of limestone and/or sand ( + PVA; L + S + PVA; L + AC + PVA and $\mathrm{CS}+\mathrm{S}+\mathrm{PVA}$ ) showed TSW above $4 \mathrm{~g}$, while those to which were added calcium silicate and active charcoal showed TSW less than $4 \mathrm{~g}$. Probably, this is due to the density of the materials used in the coating, since the limestone $\left(2.86 \mathrm{~g} / \mathrm{cm}^{3}\right)$ and sand $\left(1.53 \mathrm{~g} / \mathrm{cm}^{3}\right)$ have a density that is greater than the one for calcium silicate $\left(2.10 \mathrm{~g} / \mathrm{cm}^{3}\right)$ and charcoal $\left(0.25 \mathrm{~g} / \mathrm{cm}^{3}\right)$. Therefore, seeds coated with limestone and sand resulted in more dense layers and hence higher TSW than those coated with calcium silicate and charcoal, which provided lower TSW.

Regarding the results found for MAD and MID, it was possible to see the relation of the sand on the thickness of the coating (Table 1). The highest MAD value was observed for coating comprising $\mathrm{CS}+\mathrm{S}+\mathrm{PVA}$. The coating based on $\mathrm{L}+$ $\mathrm{S}+\mathrm{PVA}$ provided the greatest MID, followed by the coating with $\mathrm{CS}+\mathrm{S}+\mathrm{PVA}$. The shape of the sand granules may have contributed to the formation of pellets with higher diameters, since limestone and sand of $0.25 \mathrm{~mm}$ were used.

Coated seeds showed lower WC values when compared to uncoated seeds (US) (Table 1). This indicates that the materials used in the coating did not retain moisture and that the temperature of $40{ }^{\circ} \mathrm{C}$ was sufficient for drying the water applied during the coating procedure. It is noteworthy that this reduction was more pronounced in treatments where sand was used as a filler ( $\mathrm{L}+\mathrm{S}+\mathrm{PVA}$ and $\mathrm{CS}+\mathrm{S}+\mathrm{PVA})$; however, these did not differ from the treatment with $\mathrm{L}+\mathrm{AC}+\mathrm{PVA}$. The addition of this material resulted in higher exposure to hot air for drying the pellet, due to the application of a larger number of layers to them. Probably these seeds showed lower WC values due to their exposure to heat for more times compared to the seeds coated with the other materials.

Conceição et al. (2009) and Lagôa et al. (2012) also found WC values significantly lower than those found with uncoated seeds. Conceição et al. (2009) have attributed the low water content values to the coating and not to the seeds, since the seeds subjected to removal of the coating showed water content similar to the one for uncoated seeds.

As for the physiological characteristics, it was observed that in FCG there was no significant difference among treatments (Table 2). The same was observed by Nascimento et al. (2009) for carrot seeds coated with sand and microcellulose, by Peske and Novembre (2011) for millet seeds coated with different fillers (microcellulose, magnesium thermophosphate, reactive phosphate, phytic acid, dicalcium phosphate, gypsum and vermiculite) and PVA and by Tunes et al. (2014) for irrigated rice seeds coated with kaolin and carbonized rice husk. 
Table 2. First count of germination (FCG) (\%), germination speed index (GSI), mean germination time (MGT), germination (\%), abnormal seedlings (AS) (\%) and non-germinated seeds (NGS) (\%) of stylosanthes cv. Campo Grande seeds coated with the following treatments: US - uncoated seeds; L + PVA (dolomitic limestone + PVA); L + S + PVA (dolomitic limestone + sand + PVA $) ; \mathrm{L}+\mathrm{AC}+\mathrm{PVA}($ dolomitic limestone + activated carbon+ PVA); CS + PVA (calcium silicate + PVA); CS + S + PVA (calcium silicate + sand + PVA); CS + AC + PVA (calcium silicate + activated carbon + PVA).

\begin{tabular}{|c|c|c|c|c|c|c|}
\hline Treatment & FCG $(\%)$ & GSI & MGT & $\mathrm{G}(\%)$ & AS (\%) & NGS (\%) \\
\hline US & $63 \mathrm{a}$ & $16.77 \mathrm{ab}$ & $2.23 \mathrm{a}$ & $66 \mathrm{a}$ & $2 a$ & $14 \mathrm{a}$ \\
\hline $\mathrm{L}+\mathrm{PVA}$ & $51 \mathrm{a}$ & $13.33 \mathrm{~b}$ & $2.66 \mathrm{bc}$ & $53 \mathrm{~b}$ & $8 \mathrm{~b}$ & $11 \mathrm{a}$ \\
\hline $\mathrm{L}+\mathrm{S}+\mathrm{PVA}$ & $54 \mathrm{a}$ & $13.18 \mathrm{~b}$ & $2.92 \mathrm{c}$ & $61 \mathrm{ab}$ & $7 \mathrm{ab}$ & $10 \mathrm{a}$ \\
\hline $\mathrm{L}+\mathrm{AC}+\mathrm{PVA}$ & $59 \mathrm{a}$ & $16.42 \mathrm{ab}$ & $2.49 \mathrm{ab}$ & $60 \mathrm{ab}$ & $9 \mathrm{~b}$ & $7 \mathrm{a}$ \\
\hline $\mathrm{CS}+\mathrm{PVA}$ & $66 \mathrm{a}$ & $18.97 \mathrm{a}$ & $2.23 \mathrm{a}$ & $68 \mathrm{a}$ & $7 \mathrm{ab}$ & $12 \mathrm{a}$ \\
\hline $\mathrm{CS}+\mathrm{S}+\mathrm{PVA}$ & $54 \mathrm{a}$ & $14.80 \mathrm{~b}$ & $2.40 \mathrm{ab}$ & $56 \mathrm{ab}$ & $10 \mathrm{~b}$ & $14 \mathrm{a}$ \\
\hline $\mathrm{CS}+\mathrm{AC}+\mathrm{PVA}$ & $55 \mathrm{a}$ & $15.02 \mathrm{~b}$ & $2.47 \mathrm{ab}$ & $59 \mathrm{ab}$ & $6 \mathrm{ab}$ & $11 \mathrm{a}$ \\
\hline Average & 57.7 & 15.50 & 2.49 & 60.3 & 7.3 & 11.07 \\
\hline CV (\%) & 14.57 & 15.74 & 9.41 & 13.00 & 56.95 & 41.76 \\
\hline
\end{tabular}

Means followed by the same letter are not statistically different from each other by Duncan test $(p<0.05)$.

In general, seed coating causes a delay in germination rate, as reported by various authors (Silva et al., 2002; Oliveira et al., 2003a; Oliveira et al., 2003b; Mendonça et al., 2007; Conceição and Vieira, 2008). This behavior, however, was not observed for the treatments assessed in this study, since none of the treatments differed from the US. It is worth noting that treatment with CS + PVA stood out among the coatings, but did not differ from $\mathrm{L}+\mathrm{AC}+\mathrm{PVA}$.

Delay in germination can occur due to the material used in the coating procedure, which requires a physical barrier that must be overcome by the seed. However, some materials allow better diffusion of gases and water between the seed and the external environment (Nascimento et al., 2009). During the experiment it was observed that the coating with calcium silicate would cut up easily when in contact with water. Thus, the barrier imposed by coating with this material was quickly undone and, therefore, gas exchange and the water uptake by the seeds were more facilitated compared to seeds coated with other materials. This may have led to faster water absorption by these seeds.

On the other hand, the fact that the treatment with $\mathrm{L}+$ $\mathrm{AC}+\mathrm{PVA}$ did not differ statistically from the silicate may be related to charcoal characteristics. Activated carbon is obtained by pyrolysis (chemical decomposition by action of heat) of carbonaceous materials of vegetable origin, followed by chemical activation. At the end of the procedure an adsorbent material is obtained, exhibiting a highly porous structure (Monocha, 2003). Thus, the use of charcoal in such treatment may have probably granted gas exchanges, improving oxygen supply, which is essential to germination, because the limestone promotes a waterproofing effect of the coating, as has been observed in tomato seeds (Oliveira et al., 2003b).
Best MGT is related to the lowest values found for this variable, as verified for US and CS + PVA; however, these treatments did not differ from $\mathrm{L}+\mathrm{AC}+\mathrm{PVA}, \mathrm{CS}+\mathrm{S}+\mathrm{PVA}$ and $\mathrm{CS}+\mathrm{AC}+\mathrm{PVA}$ (Table 2 ). The use of calcium silicate as the filler did not cause major impediment to water absorption and gas exchanges, which gives good characteristics as a filler. Conversely, the greatest MGT was observed for seeds coated with $\mathrm{L}+\mathrm{S}+\mathrm{PVA}$, and the treatment with $\mathrm{L}+$ PVA did not differ from this one. Materials such as limestone may result in sealing the gas exchanges, associated to a high moisture retention rate, imposed by the thickness of the material layer (Silva and Nakagawa, 1998a). This limestone waterproofing effect was also observed in the coating of tomato seeds (Oliveira et al., 2003b).

The main obstacle to the use of coated seeds is in the delay generated in seed germination (Silva et al., 2002). However, despite these delays, the final germination rates are similar to those of uncoated seeds (Silva et al., 2002, Tavares et al., 2012). Although the different filling materials assessed in this study have entailed delays in germination time, only the limestone + PVA provided the small percentage of germination, $53 \%$ (Table 2). However, the treatments plus sand and charcoal $(\mathrm{L}+\mathrm{S}+\mathrm{PVA}, \mathrm{L}+\mathrm{AC}+\mathrm{PVA}, \mathrm{CS}+\mathrm{S}+$ PVA and CS + AC + PVA) showed no differences compared to limestone + PVA.

Likewise, the use of limestone in lettuce seed coating promoted reduction in seed germination (only 47\%), regardless of granulometry and pellet size formed (Silva and Nakagawa, 1998a). On the other hand, Tavares et al. (2012) have found no negative effect of limestone or aluminum silicate at a percentage of seed germination of two rice cultivars. 
This divergence noticed among different studies on seed coating occurs depending on the type of material used in the procedure and the layer thickness of coating deposited on the seeds (Pereira et al., 2011). Normally, after the seeds overcome the barrier imposed by coating, the seedlings are equal in growth velocity, forming uniform seedlings (Silva and Nakagawa, 1998b).

The seeds that have not received any coating (US) showed lower percentages of abnormal seedlings (2\%) compared to treatment with $\mathrm{L}+\mathrm{PVA}, \mathrm{L}+\mathrm{AC}+\mathrm{PVA}$ and $\mathrm{CS}+\mathrm{S}+\mathrm{PVA}$ (Table 2). Probably the arrangement formed by the particles of the fillers and the adhesive solution have promoted difficulty in gas exchanges between the seeds and the external environment, besides the need to break the barrier imposed by coating. These impediments may have boosted the malformation of seedlings, resulting in abnormal seedlings. On the other hand, the percentage of non-germinated seeds (NGS) was not affected by the coating treatments (Table 2) and therefore this result is probably due to an intrinsic characteristic of the species itself or seed lot.

With regard to assessments carried out in a greenhouse, there was a significant difference only for mean emergence time (MET) where none of the treatments differed from the US, except treatment with L + PVA; however, this delay did not affect the final quality of plants derived (Table 3 ). From these results it is possible to see the negative effect of coating only with limestone as a filler in seedling emergence time. When there is the addition of sand and charcoal to the coating with limestone, this effect is not observed, which may be related to the higher density of coating comprising only limestone, providing a major impediment to the emergence.

Table 3. Emergence (\%), emergence speed index (ESI), mean emergence time (MET), shoot length (SL) (cm), root length (RL) (cm), fresh mass of shoot (FMS) (mg/plant), dry mass of shoot (DMS) (mg/plant), fresh mass of root (FMR) (mg/ plant) and dry mass of root (DMR) (mg/plant) of stylosanthes cv. Campo Grande plants derived from seeds coated with the following treatments: US - uncoated seeds; L + PVA (dolomitic limestone + PVA); L + S + PVA (dolomitic limestone + sand + PVA); L + AC + PVA (dolomitic limestone + activated carbon+ PVA); CS + PVA (calcium silicate + PVA) $; \mathrm{CS}+\mathrm{S}+\mathrm{PVA}$ (calcium silicate + sand + PVA); CS + AC + PVA (calcium silicate + activated carbon + PVA)

\begin{tabular}{|c|c|c|c|c|c|c|c|c|c|}
\hline Treatment & $\mathrm{E}(\%)$ & ESI & MET & SL & RL & FMS & DMS & FMR & DMR \\
\hline US & $64 \mathrm{a}$ & $8.12 \mathrm{a}$ & $4.91 \mathrm{a}$ & $1.70 \mathrm{a}$ & $11.07 \mathrm{a}$ & $46.31 \mathrm{a}$ & $5.66 \mathrm{a}$ & $17.88 \mathrm{a}$ & $4.90 \mathrm{a}$ \\
\hline $\mathrm{L}+\mathrm{PVA}$ & $60 \mathrm{a}$ & $6.72 \mathrm{a}$ & $6.24 b$ & $1.87 \mathrm{a}$ & $10.55 \mathrm{a}$ & $48.65 \mathrm{a}$ & $4.87 \mathrm{a}$ & $19.44 \mathrm{a}$ & $4.89 \mathrm{a}$ \\
\hline $\mathrm{L}+\mathrm{S}+\mathrm{PVA}$ & $52 \mathrm{a}$ & $5.92 \mathrm{a}$ & $5.74 \mathrm{ab}$ & $1.98 \mathrm{a}$ & $10.22 \mathrm{a}$ & $44.21 \mathrm{a}$ & $2.41 \mathrm{a}$ & $18.96 \mathrm{a}$ & $5.10 \mathrm{a}$ \\
\hline $\mathrm{L}+\mathrm{AC}+\mathrm{PVA}$ & $57 \mathrm{a}$ & $6.69 \mathrm{a}$ & $5.78 \mathrm{ab}$ & $1.88 \mathrm{a}$ & $11.04 \mathrm{a}$ & $45.01 \mathrm{a}$ & $3.90 \mathrm{a}$ & $19.30 \mathrm{a}$ & $5.28 \mathrm{a}$ \\
\hline $\mathrm{CS}+\mathrm{PVA}$ & $61 \mathrm{a}$ & $7.70 \mathrm{a}$ & $5.25 \mathrm{ab}$ & $1.79 \mathrm{a}$ & $11.01 \mathrm{a}$ & $59.72 \mathrm{a}$ & $7.92 \mathrm{a}$ & $23.67 \mathrm{a}$ & $5.74 \mathrm{a}$ \\
\hline $\mathrm{CS}+\mathrm{S}+\mathrm{PVA}$ & $56 \mathrm{a}$ & $6.99 \mathrm{a}$ & $5.34 \mathrm{ab}$ & $1.94 \mathrm{a}$ & $10.09 \mathrm{a}$ & $47.59 \mathrm{a}$ & $4.05 \mathrm{a}$ & $17.78 \mathrm{a}$ & $4.68 \mathrm{a}$ \\
\hline $\mathrm{CS}+\mathrm{AC}+\mathrm{PVA}$ & $51 \mathrm{a}$ & $7.03 \mathrm{a}$ & $4.86 \mathrm{a}$ & $1.85 \mathrm{a}$ & $11.11 \mathrm{a}$ & $46.38 \mathrm{a}$ & $5.15 \mathrm{a}$ & $18.31 \mathrm{a}$ & $4.77 \mathrm{a}$ \\
\hline Average & 57.14 & 7.02 & 5.45 & 1.86 & 10.73 & 48.27 & 4.85 & 19.33 & 5.05 \\
\hline $\mathrm{CV}(\%)$ & 13.84 & 19.43 & 6.09 & 11.30 & 12.20 & 20.48 & 72.81 & 24.86 & 15.67 \\
\hline
\end{tabular}

Means followed by the same letter are not statistically different from each other by Duncan test $(\mathrm{p}<0.05)$

As mentioned, none of the assessed treatments has damaged the seedling emergence in this work; however, some authors have observed a negative effect of coating for this variable. The use of limestone in lettuce seed coating has promoted a decrease in the percentage of emerged seedlings in relation to the control and coating with sand or sand + limestone (Silva and Nakagawa, 1998b) and such results differ from that observed in this study. Likewise, Santos et al. (2010) have also found an adverse effect of limestone in the emergence of brachiaria cv. Marandu plants. According to the authors, the coatings that resulted in worst emergence percentages were limestone + PVA; limestone + bentonite + PVA and sand + bentonite + polymer (19, 16 and 18\%, respectively), and the latter also showed the lowest values of ESI (0.99).
At 30 days after sowing, the plants did not differ in length (SL and RL), fresh mass (FMS and FMR) and dry mass (DMS and DMR) of shoot and root compared to plants obtained from US. The results have permitted to infer that none of the treatments has damaged plant emergence and early seedling development; therefore, they are promising in the coating of the seeds of this Fabaceae. Therefore, advances in the use of these coatings are on the incorporation of micronutrients, insecticides, fungicides and growth regulators among others, to improve the efficiency of application thereof, as well as the yield of the crop. Silva et al. (2002) have also found no differences in dry mass of shoot and root of seedlings derived from lettuce seeds coated with bentonite and PVA.

With regard to ESI and MET, it is expected that their responses be equivalent, since these variables are about 
speed and time, which are closely related. However, it was possible to find a different behavior for the treatment with L + PVA for MET, which differed from the control, which was not observed for ESI (Table 3). This happened probably due to the large variability observed for ESI $(\mathrm{AC}=19.43 \%$ ) in relation to MET $(\mathrm{AC}=6.09 \%$ ) (Table 3$)$. Which justifies why relatively large differences in the ESI values were not statistically significant, indicating that the coating treatments promoted a uniformity in the initial seedling growth.

The use of glue based on polyvinyl acetate (PVA) in this study has not proved to be a problem for seed germination and plant emergence. On the other hand, Silva et al. (2002) have observed that the use of $75 \%$ of bentonite $+25 \%$ of PVA has resulted in lower values of GSI (33), while the use of $100 \%$ of PVA has not differed from control for the coated seeds of lettuce.

From the data observed in Tables 2 and 3 it can be seen that the behavior of the coated seeds has not followed the same pattern for testing in germination chamber and greenhouse. Probably this was due to the fact that in a germination chamber the conditions are controlled throughout the test, unlike the conditions in a greenhouse, where the seedlings are exposed to temperature and humidity variations. In addition, the moisture provided by the substrate in a greenhouse around the seeds, and a larger contact surface between seeds and substrate, may have contributed for the coating to fall apart more easily, contrary to what is expected from the paper substrate in a gerbox.

\section{Conclusions}

The coating reduces the water content.

The coating with limestone + PVA glue and limestone + sand + PVA glue increases the germination time; however, no treatment affects the physiological quality of seeds.

The coating comprising calcium silicate and PVA glue stood out for the variables germination speed index and fresh and dry mass of shoot and root in the coating of stylosanthes cv. Campo Grande seeds.

\section{Referências}

BAUDET, L.; PERES, W. Recobrimento de sementes. Seed news, v.8, p.20-23. 2004

BRASIL. Ministério da Agricultura Pecuária e Abastecimento. Regras para análise de sementes. Ministério da Agricultura Pecuária e Abastecimento. Secretaria de Defesa Agropecuária. Brasília: MAPA/ACS, 2009. 395p. $\mathrm{http} / / /$ www.agricultura.gov.br/arq editor/ file/laborat $\% \mathrm{c} 3 \% \mathrm{~b} 3$ rio/ sementes/regras $\% 20$ para $\% 20$ analise $\% 20 \mathrm{de} \% 20$ sementes.pdf
CONCEIÇÃO, P.M.; VIEIRA, H.D. Qualidade fisiológica e resistência do recobrimento de sementes de milho. Revista Brasileira de Sementes, v.30, p.48-53, 2008. http://www.scielo.br/pdf/rbs/v30n3/07.pdf

CONCEIÇÃO, P.M., VIEIRA, H.D., SILVA, R.F., CAMPOS, S.C. Germinação e vigor de sementes de milho recobertas e viabilidade do inóculo durante o armazenamento. Ciência e Agrotecnologia, v.33, p.765-772, 2009. http://www.scielo.br/pdf/cagro/v33n3/a15v33n3.pdf

EDMOND, J.B, DRAPALA, W.J. The effects of temperature, sand and soil, and acetone on germination of okra seed. Proceedings of the American Society for Horticultural Science, v.71, p.428-434, 1958.

EMBRAPA GADO DE CORTE. Cultivo e uso do estilosantes. EMBRAPA Gado de Corte - Campo Grande, 2007. 11p. (Comunicado Técnico, 105). http://www.cnpgc.embrapa.br/publicacoes/cot/pdf/Cot105.pdf

FERRAZ, J.B.S.; FELÍCIO, P.E. Production systems - An example from Brazil. Meat Science, v.84, p.238-243, 2010.http://www.usp.br/gmab/ publica/msjbsf2010.pdf

GADOTTI, C.; PUCHALA, B. Revestimento de sementes. Informativo Abrates, v.20, p.70-71, 2010. http://www.abrates.org.br/portal/images/ stories/informativos/v20n3/minicurso03.pdf

LAGÔA, A.O.; FERREIRA, A.C; VIEIRA, R.D. Plantability and moisture content of naked and pelleted seeds of supersweet $\left(\mathrm{Sh}_{2}\right)$ corn during cold storage conditions. Revista Brasileira de Sementes, v.34, n.1, p.39-46, 2012. http://www.scielo.br/pdf/rbs/v34n1/a05v34n1.pdf

LOPES, A.C.A.; NASCIMENTO, W.M. Peletização em sementes de hortaliças. EMBRAPA Hortaliças - Brasília, 2012. 28p. (Documentos, 137) http://www.cnph.embrapa.br/paginas/serie documentos/publicacoes2012/ doc_137.pdf

MAGUIRE, J.D. Speeds of germination-aid selection and evaluation for seedling emergence and vigor. Crop Science, v.2, p.176-177, 1962.

MEDEIROS, E.M.; BAUDET, L.; PERES, W.B.; EICHOLZ, E.D. Modificações na condição física das sementes de cenoura em equipamento de recobrimento. Revista Brasileira de Sementes, v.26, n.2, p.70-75, 2004. http://www.scielo.br/pdf/rbs/v26n2/24491.pdf

MENDONCA, E.A.F.; CARVALHO, N.M.; RAMOS, N.P. Revestimento de sementes de milho superdoce ( $\left.\mathrm{Sh}_{2}\right)$. Revista Brasileira de Sementes, v.29, n.2, p.68-79, 2007. http://www.scielo.br/pdf/rbs/v29n2/v29n2a10.pdf

MONOCHA, S.M. Porous carbons. Sadhana, v.28, p.335-348, 2003. http://www.ias.ac.in/sadhana/Pdf2003Apr/Pe1070.pdf

NASCIMENTO, W.M.; SILVA, J.B.C.; SANTOS, P.E.C., CARMONA, R. Germinação de sementes de cenoura osmoticamente condicionadas e peletizadas com diversos ingredientes. Horticultura Brasileira, v.27, p.12-16, 2009. http://www.scielo.br/pdf/hb/v27n1/03.pdf

OLIVEIRA, J.A.; PEREIRA, C.E.; GUIMARÃES, R.M.; VIEIRA, A.R.; SILVA, J.B.C. Desempenho de sementes de pimentão revestidas com diferentes materiais. Revista Brasileira de Sementes, v.25, n.2, p.3647, 2003a. http://www.scielo.br/pdf/rbs/v25n2/19647.pdf

OLIVEIRA, J.A.; PEREIRA, C.E; GUIMARÃES, R.M; VIEIRA, A.R.; SILVA, J.B.C. Efeito de diferentes materiais de peletização na deterioração de sementes de tomate durante o armazenamento. Revista Brasileira de Sementes, v.25, n.2, p.20-27, 2003b. http://www.scielo.br/ $\mathrm{pdf} / \mathrm{rbs} / \mathrm{v} 25 \mathrm{n} 2 / 19645 . \mathrm{pdf}$ 
PEREIRA, C.E.; OLIVEIRA, J.A.; GUIMARÃES, R.M.; VIEIRA, A.R.; EVANGELISTA, J.R.E.; OLIVEIRA, G.E. Tratamento fungicida e peliculização de sementes de soja submetidas ao armazenamento. Ciência e Agrotecnologia, v.35, p.158-164, 2011. http://www.scielo.br/ pdf/cagro/v35n1/a20v35n1.pdf

PESKE, F.B.; NOVEMBRE, A.D.L.C. Pearl millet seed pelleting. Revista Brasileira de Sementes, v.33, n.2, p.352-362, 2011. http://www. scielo.br/pdf/rbs/v33n2/18.pdf

SANTOS, F.C.; OLIVEIRA, J.A.; VON PINHO, E.V.R..; GUIMARÃES, R.M.; VIEIRA, A.R. Tratamento químico, revestimento e armazenamento de sementes de Brachiaria brizantha cv. Marandu. Revista Brasileira de Sementes, v.32, n.3, p.69-78, 2010. http://www.scielo.br/pdf/rbs/v32n3/ v32n3a08.pdf

SHELTON, H.M.; FRANZEL, S.; PETERS, M. Adoption of tropical legume technology around the world: analysis of success. Tropical Grasslands, v.39, p.198-209, 2005. http://www.tropicalgrasslands.asn. au/Tropical\%20Grasslands\%20Journal\%20archive/PDFs/Vol_39_2005/ Vol 39 04 2005 pp198 209.pdf

SILVA, F.A.S. ASSISTAT - Assistência Estatística, versão 7.6. Universidade Federal de Campina Grande - PB. 2013.

SILVA, J.B.C.; NAKAGAWA, J. Metodologia para avaliação de materiais cimentantes para peletização de sementes. Horticultura Brasileira, v.16, p.31-37, 1998a. http://www.abhorticultura.com.br/biblioteca/arquivos/ Download/biblioteca/hb_16_1.pdf
SILVA, J.B.C.; NAKAGAWA, J. Confecção e avaliação de péletes de sementes de alface. Horticultura Brasileira, v.16, p.151-158, 1998b. http://www.abhorticultura.com.br/biblioteca/arquivos/Download/ biblioteca/hb 16 2.pdf

SILVA, D. J., QUEIROZ, A.C. Análise de alimentos: métodos químicos e biológicos. Viçosa, MG: UFV, 2006. 235p.

SILVA, J.B.C.; SANTOS, E.C.; NASCIMENTO, W.M. Desempenho de sementes peletizadas de alface em função do material cimentante e da temperatura de secagem dos péletes. Horticultura Brasileira, v.20, p.6770, 2002. http://www.scielo.br/pdf/hb/v20n1/14420

TAVARES, L.C.; RUFINO, C.A.; DÖRR, C.S.; BARROS, A.C.S.A.; PESKE, S.T. Performance of lowland rice seeds coated with dolomitic limestone and aluminum silicate. Revista Brasileira de Sementes, v.34, n.2, p.202-211, 2012. http://www.scielo.br/pdf/rbs/v34n2/03.pdf

TUNES, L.V.M.; FONSECA, D.A.R.; MENEGHELLO, G.E.; REIS B.B.; BRASIL, V.D.; RUFINO, C.A.; VILLELA, F.A. Qualidade fisiológica, sanitária e enzimática de sementes de arroz irrigado recobertas com silício. Revista Ceres, v.61, p.675-685, 2014. http:// www.ceres.ufv.br/ceres/revistas/V61N005P01013.pdf

Journal of Seed Science, v.37, n.2, p.117-124, 2015 